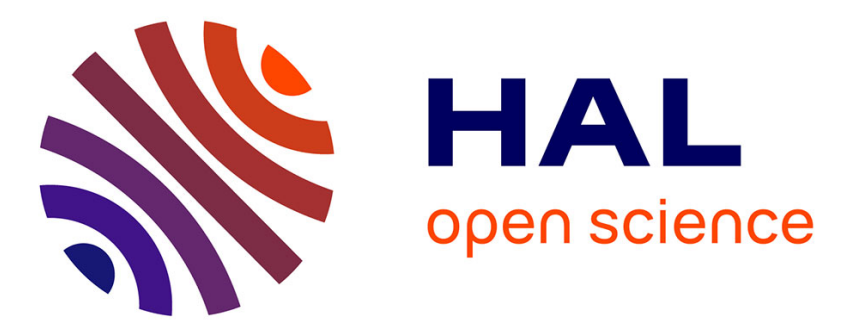

\title{
The impact of salespeople's relational behaviors and organizational fairness on customer loyalty: An empirical study in B-to-B relationships
}

Juliet Poujol, Béatrice Siadou-Martin, David Vidal, Ghislaine Pellat

\section{- To cite this version:}

Juliet Poujol, Béatrice Siadou-Martin, David Vidal, Ghislaine Pellat. The impact of salespeople's relational behaviors and organizational fairness on customer loyalty: An empirical study in B-to-B relationships. Journal of Retailing and Consumer Services, 2013, 20 (5), pp.429-438. 10.1016/j.jretconser.2013.03.005 . hal-01992773

\section{HAL Id: hal-01992773 \\ https://hal.umontpellier.fr/hal-01992773}

Submitted on 26 Jan 2021

HAL is a multi-disciplinary open access archive for the deposit and dissemination of scientific research documents, whether they are published or not. The documents may come from teaching and research institutions in France or abroad, or from public or private research centers.
L'archive ouverte pluridisciplinaire HAL, est destinée au dépôt et à la diffusion de documents scientifiques de niveau recherche, publiés ou non, émanant des établissements d'enseignement et de recherche français ou étrangers, des laboratoires publics ou privés. 


\title{
The impact of salespeople's relational behaviors and organizational fairness on customer loyalty: An empirical study in B-to-B relationships
}

\author{
Juliet F. Poujol ${ }^{\mathrm{a}, *}$, Béatrice Siadou-martin ${ }^{\mathrm{b}, 1}$, David Vidal ${ }^{\mathrm{b}, 2}$, Ghislaine Pellat ${ }^{\mathrm{c}, 3}$ \\ ${ }^{a}$ MRM-Montpellier Research in Management, INSEEC Paris, 27 Avenue Claude Vellefaux, 75010 Paris, France \\ ${ }^{\mathrm{b}}$ MRM-Montpellier Research in Management, IUT-University of Montpellier 2, 99 avenue d'Occitanie, 34095 Montpellier Cedex 5, France

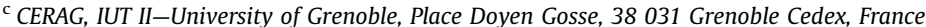

\begin{abstract}
ARTICLE INFO
ABSTRACT : Although customer loyalty has proved to be a powerful determinant of firms' profits, the drivers of loyalty in B-to-B relationships are still unclear. Recognizing that both interpersonal and interorganiza-tional level variables are needed to predict customer loyalty, the aim of this study is to investigate the combined effects of salespersons' relational behavior and organizational fairness in predicting customer satisfaction and loyalty. Results from a field survey in a B-to-B setting show that buyer loyalty is largely determined by the quality of the interpersonal relationship with the seller. Perceived fairness is central for building overall customer satisfaction and loyalty toward the supplier.
\end{abstract}

Keywords : Customer loyalty; Salesperson relational behaviors : Fairness ; B-to-B relationships

\section{Introduction}

An increasing number of contributions based on justice theories have recently appeared to predict customer satisfaction, especially in the service and complaining behavior literature (Maxham and Netemeyer, 2003; Vázquez-Casielles et al., 2010). However, although selling is central to service delivery processes, to the best of our knowledge, no empirical study has investigated the role played by perceptions of fairness in the buyer-seller relationship. This absence is particularly regrettable, since the selling process itself implies implicit promises of fairness that will be assessed by the customer. In the sale service experience or "servuction" as defined by Eiglier and Langeard (1987), the customer expects to be treated fairly not only in the tangible but also in the intangible aspects of the exchange process. Such fairness is also expected in the way the service is delivered. Indeed, Oliver and Swan (1989) have highlighted the significant impact of interpersonal equity in satisfaction judgments.

Research on salesperson management suggests that salespeople's behavior not only shapes the seller-buyer relationship but

\footnotetext{
* Corresponding author. Tel.: +33 671828859.

E-mail addresses: jpoujol@groupeinseec.com (J.F. Poujol), beatrice.siadoumartin@univ-montp2.fr (B. Siadou-martin), david.vidal@univ-montp2.fr (D. Vidal), ghislaine.pellat@iut2.upmf-grenoble.fr (G. Pellat).

1 Tel.: +33 629688654

2 Tel.: +33678940205

3 Tel.: +33 608246727.
}

also the selling firm-buying firm partnership. More specifically, a salesperson's customer orientation has been shown to influence customer satisfaction with the salesperson, satisfaction with the retailer, and ultimately satisfaction with the selling firm (Goff et al., 1997). Our framework is based on this multi-level approach.

Existing research on the analysis of B-to-B relationships suggests that relationship quality and loyalty can be defined at two levels: an interpersonal level (relationship with the seller) and an organizational level (relationship with the firm). Contributions concerned with multi-level loyalty emphasize that the interpersonal and the interorganizational levels are not independent. Indeed, customer loyalty toward the salesperson has been shown to increase loyalty toward the selling firm (Macintosh and Lockshin, 1997; Reynolds and Beatty, 1999). Likewise, customer loyalty to the selling firm is dependent upon salesperson-related variables (Beatty et al., 1996; Berry, 1995). For example, Macintosh (2007) found significant relations between relationship quality at the interpersonal level and positive outcomes at the organizational level.

According to these conclusions, the present study investigates the combined and interactive effects of interpersonal and interorganizational variables on customer loyalty. More specifically, the aim of this paper is to develop a conceptual framework that considers seller relational behaviors (customer orientation and team selling) and organizational fairness (distributive and procedural fairness) as antecedents of customer satisfaction (satisfaction with the salesperson and with the firm) and loyalty (anticipation of future interactions with the salesperson and loyalty toward the firm) in a B-to-B setting. Consistent with the meta-analysis on 
relationship marketing (Palmatier et al., 2006), the proposed model integrates relational antecedents (salesperson relational behaviors and fairness), relational outcomes (loyalty) and one relational mediator (satisfaction).

The manuscript is structured as follows: after reviewing relevant literature (Section 2) on key conceptual issues regarding relationship processes at the interpersonal and interorganizational levels and considering the potential interactions between these two levels, we introduce a framework modeling the influence of salesperson behaviors and organizational fairness on customer satisfaction and loyalty. The methodological aspects of the empirical study designed to assess the validity and reliability of the proposed model are then presented (Section 3). The research method section describes the research setting, the data collection and data analysis procedures. A discussion of research findings (Section 4), contributions, and limitations (Section 5) concludes the paper.

\section{Theoretical background}

This section describes the theoretical underpinnings and empirical evidence supporting the proposed framework (see Fig. A1). After examining interpersonal interactions in commercial relationships, we focus on the organizational level by examining the role played by fairness assessments. The interactions between the interpersonal and organizational levels are then investigated.

\subsection{Interpersonal determinants of customer loyalty}

In B-to-B relationships, the selling process is not limited to an isolated exchange between two independent firms. Rather it is the outcome of an ongoing relationship between two business partners. Instead of simply negotiating, parties are motivated by the so-called pie expansion, i.e. the collaborative process of creating mutually beneficial strategic outcomes between the two partners (Jap, 1999). In this context, salespeople constitute a strategic interface shaping service quality and ultimately customer loyalty (Grewal and Sharma, 1991; Biong and Selnes, 1996; Humphreys and Williams, 1996). Indeed, salesperson relational actions and behaviors have a significant impact on customer satisfaction and relationship quality (Oliver and Swan, 1989). Humphreys and Williams (1996) even demonstrated that the attributes of the interpersonal process have a greater influence on buyer satisfaction than the attributes of the product itself. According to Williams and Attaway (1996), the salesperson's customer orientation (CO) is a key factor in explaining how buyers assess sellers' behaviors and is thus central to the development of long-term relationships. Based on the seminal model of Schultz and Evans (2002), Guenzi et al. (2009) demonstrated that CO and team selling are prime determinants of buyer satisfaction. We discuss these two concepts in the following paragraphs.

\subsubsection{Customer orientation}

Consistent with the seminal definition proposed by Saxe and Weitz (1982), Williams and Attaway (1996) define customer orientation (CO) as "a philosophy and behavior directed toward determining and understanding the needs of the target buyer and adapting the selling organization's response in order to satisfy those needs better than the competition" (p. 39). CO has been shown to have a significant influence on customer purchasing decisions. Saxe and Weitz (1982) indicate that CO provides customers with the required information to make the decisions that will best satisfy their long-term needs. $\mathrm{CO}$ is a major antecedent of customer satisfaction and relationship quality (Dorsch et al., 1998).

Goff et al. (1997) show that customers are more likely to be satisfied with salespeople as the perceived level of $\mathrm{CO}$ increases. By being customer oriented, salespersons are more likely to identify customer needs and to match their presentation to those requirements, thereby increasing customer satisfaction. Likewise, Williams and Attaway (1996) and Liu and Leach (2001) have demonstrated that the buyer-seller relationship quality as perceived by the customer improves as the salesperson's relational behaviors directed toward the customer increase. Following this reasoning, we postulate the following hypothesis:

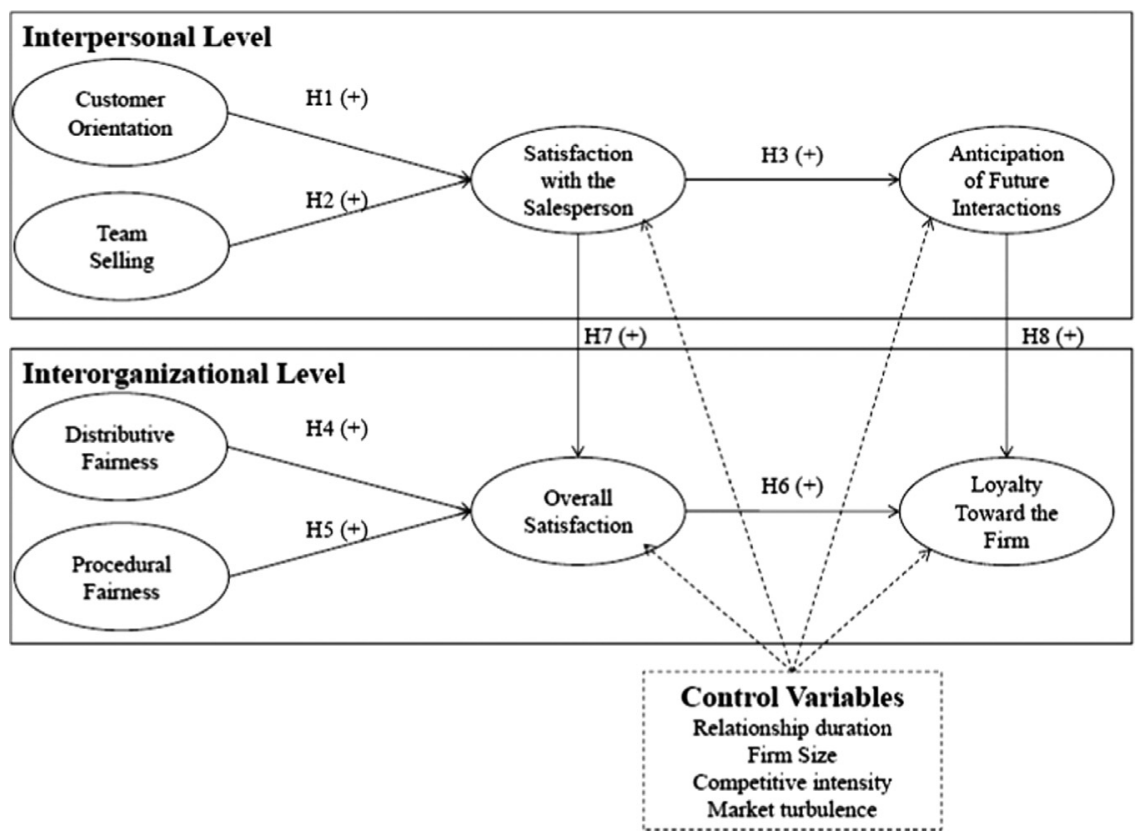

Fig. A1. Theoretical model and proposed hypotheses.. 
H1: Salesperson CO has a positive influence on the level of customer satisfaction with the salesperson.

\subsubsection{Team selling}

According to Workman et al. (2003), team use may be defined as the extent to which teams are formed to coordinate activities for key accounts. Guenzi et al. (2009) go further and define team selling as the capability of the seller to mobilize a team. A salesperson displaying high team selling abilities is perceived by the buyer as able to work closely with colleagues and to coordinate the working team. The importance of team selling for strategic account managers has been empirically documented by Guenzi et al. (2009). In fact, they suggest that the efforts made by the strategic account manager to coordinate the resources mobilized are essential. Likewise, Perry et al. (1999) suggest that, under conditions of high task complexity, the need for an effective team selling process is heightened. Indeed, team selling is usually adopted in complex buyer-seller situations, where dedicated and individualized treatment is required.

Because B-to-B relationships usually involve durability and high complexity, customers do not interact with a single sales representative. Consequently, coordination and leadership competencies seem to be crucial for the quality of the relationship. Coordination efforts may be manifested in the team selling formation and in an ongoing effort to work together. In line with the preceding considerations, we put forward the following hypothesis:

$\mathrm{H} 2$ : Team selling has a positive impact on the level of customer satisfaction with the salesperson.

\subsubsection{Salesperson relationship}

The positive impact that satisfaction with the salesperson has on the buyer's anticipation of future interactions has been empirically documented (Crosby et al., 1990; Biong and Selnes, 1996). For example, Biong and Selnes (1996) showed that relational cooperation is enhanced by a combination of structural bonding and interpersonal relationships. Crosby et al. (1990) demonstrated that a customer's likelihood of seeking future contact with a salesperson is mainly determined by the quality of the prior customersalesperson relationship. They proposed that relational behaviors positively impact future interactions through satisfaction with the salesperson. Consequently, we postulate the following:

H3: The buyer's satisfaction with the salesperson has a positive impact on the buyer's anticipation of future interactions with the salesperson.

\subsection{Interorganizational determinants of customer loyalty}

Satisfaction and loyalty toward the selling firm have proved to be key indicators of the health of interorganizational relationships (Palmatier et al., 2006). Satisfaction has been defined as an overall evaluation of the relationship based on the outcomes of previous experiences (Oliver, 1981; Bitner and Hubbert, 1994), while loyalty has conative consequences such as positive word of mouth, patronage and repurchase intentions. Within the consumer and the marketing channel literature, a growing body of evidence suggests that fairness perceptions are significant determinants of customer satisfaction and loyalty toward firms. For example, Maxham and Netemeyer (2003) demonstrated how different levels of fairness may affect a firm's profits. According to Bagozzi (1975) and Berry et al. (1994), each exchange within a particular relationship implies implicit promises of fair play and expectations of fair treatment. Indeed, if customers believe they are treated unfairly, they are more likely to become hostile, to distrust their partner and to end the relationship. Justice theories are thus useful in explaining the nature of interfirm interactions. Since organizations develop specific policies and procedures to deliver services or products, they can be perceived as more or less fair according to how commercial exchanges are conducted. Studies in the literature on marketing and organizational behavior indicate that individuals who are involved in commercial exchanges base their perceptions of fairness on relational outcomes and processes. Moreover, existing contributions suggest that customers evaluate their suppliers mainly in terms of distributive and procedural fairness. In this perspective, the proposed model is based on Kumar et al. (1995) conceptualization of fairness in B-to-B setting.

\subsubsection{Distributive fairness}

Based on equity theory (Adams, 1963, 1965), distributive fairness perceptions refer to judgments about the fairness of the outcomes individuals receive compared to their initial input (internal equity). At the same time, distributive fairness implies an interpersonal comparison (external equity), which has been defined as the "fairness, rightness, or deservingness in comparison to other entities, whether real or imaginary, individual or collective, person or non-person" (Oliver, 1997).

In the B-to-C setting, the positive relationship between distributive fairness and consumer satisfaction is well established, especially in the service recovery literature. Indeed, existing contributions indicate that distributive fairness assessments have a significant impact on satisfaction with complaint handling (Goodwin and Ross, 1992; Tax et al., 1998) and on transactional satisfaction with service delivery (Bolton and Lemon, 1999).

Likewise, in the marketing channel literature, Frazier et al. (1988) define distributive fairness as "the division of benefits and burdens". This definition, however, does not imply that inputs or outcomes are necessarily equally divided between parties; rather it suggests that fairness requires profits to be distributed proportionally, based on the investments made by each partner. Research on the topic makes it clear that equity is a key aspect for long-term cooperation. Indeed equity (or fair dealing) has been shown to be an important criterion for assessing interorganizational relationships (Gundlach and Murphy, 1993; Ring and Van de Ven, 1994) and a powerful antecedent of overall relationship satisfaction (Jap, 2001; Brown et al., 2006). In line with this reasoning, we hypothesize the following:

H4: Distributive fairness has a positive influence on the buying firm's satisfaction with the selling firm.

\subsubsection{Procedural fairness}

In examining various dispute resolution processes, Thibaut and Walker (1978) demonstrated that individuals could accept less favorable outcomes when they felt that decision-making processes were fair and that they had been treated fairly. In other words, individuals are more likely to consent to sacrifices if they believe that procedural fairness has been respected. Procedural fairness refers to judgments made about the fairness of the rules or policies used to make decisions or allocate resources. Within the marketing channel literature, procedural fairness has been defined as a "reseller's perception of the fairness of the supplier's procedures and processes in relation to its resellers" (Kumar et al., 1995).

In a study examining the different aspects of service recovery policies, Clemmer (1993) identified flexibility and efficiency as aspects of procedural fairness. Furthermore, the literature provides numerous examples showing that procedural fairness matters in post-complaint behavior. Consumers who view procedures and policies as fair are satisfied. Previous research supports this relationship in B-to-C (Saxby et al., 2000; Sparks and McCollKennedy, 1998; Tax et al., 1998) and B-to-B settings (Kumar et al., 
1995; Brown et al., 2006). In line with the preceding conclusions, we hypothesize the following:

H5: Procedural fairness has a positive influence on the buying firm's satisfaction with the selling firm.

\subsubsection{Fairness and long-term relationship}

The intimate relationship connecting satisfaction to loyalty is widely acknowledged in the marketing literature. Research shows that satisfied customers are more likely to be loyal than dissatisfied ones (Fornell, 1992; Fornell and Wernefelt, 1987; Parasuraman et al., 1991; Reichheld and Sasser, 1990). Indeed satisfaction has proved to be a major antecedent to loyalty (Bitner, 1990; Dick and Basu, 1994; Fornell et al., 1996). The same conclusions apply in Bto-B relationships. For example, based on the results of a metaanalysis, Geyskens et al. (1999) found that buyer satisfaction is a key driver of long-term interfirm partnerships. Prior contributions (Ganesan, 1994; Mittal and Kamakura, 2001) indicate that customer satisfaction not only affects customer loyalty directly but also influences behavioral variables indicative of a customer's longterm orientation toward a relationship (e.g. patronage intentions, positive WOM intentions, etc.). Based on the above findings, we hypothesize the following:

H6: The buying firm's overall satisfaction has a positive impact on its loyalty toward the selling firm.

\subsection{Interaction between the interpersonal level and the organizational level}

In addition to the individual effects of the salesperson and organizational fairness on customer loyalty, the proposed framework assumes an interactive effect between the interpersonal and the interorganizational levels. More specifically, the present model suggests that satisfaction at the organizational level is partly conditioned by the extent to which interpersonal interactions are satisfying. As previously mentioned, buyers evaluate suppliers on the basis of the various benefits offered by the supplier, including the salesperson. Satisfaction with interpersonal processes has even proved to be more effective in explaining customer satisfaction than the characteristics of the product itself (Humphreys and Williams, 1996). Given its significant impact in predicting customer assessments, we propose that salespersonderived satisfaction is associated with the company overall satisfaction. Previous research gives credence to the idea that customers' positive feelings toward the salesperson can be "transferred" to the company (Beatty et al., 1996). For example, Goff et al. (1997) found that satisfaction with the salesperson is an antecedent of overall satisfaction with a dealer. Likewise, Oliver and Swan (1989), Crosby et al. (1990) and Reynolds and Beatty (1999) observed that satisfaction toward the salesperson has a positive influence on satisfaction with the supplier. We therefore put forward the following hypothesis:

H7: Satisfaction with the salesperson has a positive influence on the buying firm's overall satisfaction.

As previously mentioned, loyalty has received considerable attention from both academics and practitioners because building customer relationship and firm loyalty yields positive returns in terms of word-of-mouth, turnover, and patronage intentions. Defined as a buyer's overall attachment or deep commitment to a product, service, brand or organization (Oliver, 1999), customer loyalty may thus take different forms and may be directed to different objects. This is particularly true in B-to-B relationships where loyalty may be defined at the interpersonal (loyalty toward the salesperson) and interorganizational (loyalty toward the firm) levels. Nevertheless, the links between interpersonal loyalty and interorganizational loyalty are complex. Indeed, customer loyalty toward the salesperson has been shown to increase loyalty toward the selling firm (Macintosh and Lockshin, 1997; Reynolds and Beatty, 1999). At the same time, the customer may decide to end a relationship with a company in order to stay loyal to a salesperson that would switch to a competitor. Likewise, Goff et al. (1997) found that positive feelings toward salespeople can be transferred to the firm. Consequently, the proposed model suggests that loyalty toward the salesperson has a positive influence on loyalty toward the firm. In other words, we propose that a customer who is highly loyal to his/her salesperson and anticipates having future interactions with him/her is also highly loyal to the firm that supports and employs this salesperson. Therefore, we test the following hypothesis:

H8: Anticipation of future interactions with the salesperson has a positive impact on a customer's loyalty toward the selling firm.

\section{Research method}

A field survey and the PLS approach were used to assess the proposed research hypotheses. Data were collected from 130 buyers working in the French bio-diagnostic sector as detailed in the following paragraph.

\subsection{Research setting and data collection}

The bio-diagnostic sector was chosen as a research setting because of the complex nature of the services involved. The selling process usually implies long-term negotiations aimed at building a unique selling proposal to customers (in terms of products/ services, financial terms, etc.) and extended after-sale services. Furthermore, suppliers provide customers with significant information regarding the probable evolution of the sector (in terms of practices, competences, technology, etc.). Salespeople consequently serve as key contact points for buyers before, during and after purchase episodes. Given the complex nature of these services, both salespersons and purchasers are highly involved in the commercial exchange. The salesforce is mobilized far beyond the individual salesperson, with the possible intervention of a number of the company's product managers.

This research used a convenience sample consisting of buyers working in biomedical laboratories, scientific research institutes, private or public scientific laboratories, and medical laboratories.

Respondents were first contacted by phone. The questionnaire was then attached to an email sent to active and knowledgeable buyers in the bio-diagnostic sector. Respondents were asked to give their opinion on the relationship with one chosen supplier, to explain the reason for their choice, and to evaluate the duration of the relationship and the frequency of contact methods (mail, phone, visit, etc.). They were also asked to assess the quality of salesperson behavior and of organizational fairness as well as their level of satisfaction with, and loyalty toward, the salesperson and the firm. Demographic questions included gender, position in the company, firm's size and main business activities.

In all, 220 buyers were eventually reached and invited to answer the web survey. 130 usable questionnaires were electronically returned, for a response rate of $59 \%$. Because the respondents are experts in the field, they are very familiar with the products and devices used in this sector. The majority of respondents were male (62\%), aged between 31 and 50 (58\%), and had worked in SMEs (85.3\%) as buyers for at least 6 years (61.1\%). The representativeness of the sample used in this research was 
assessed by comparing the characteristics of the individuals included in the final sample with the characteristics of the observed population. Based on the available data concerning the overall sector, our sample is relatively comparable to the observed population in terms of gender, buyers' age, and firm size.

All the constructs used in this study were based on prior contributions, measured using five-point Likert scales ranging from "totally disagree" to "totally agree", and constructed in the reflective mode. Table A1 details the final scale items. Customer orientation was measured with the scale developed by Thomas et al. (2001). Team selling was operationalized using the Guenzi et al. (2009) scale. We used Ramsey and Sohi's (1997) scales to measure satisfaction with the salesperson and anticipation of future interaction. Cannon and Perreault's (1999) instruments were used to measure satisfaction with the firm and loyalty toward the firm. Distributive fairness and procedural fairness were estimated with items from the scales of Kumar et al. (1995).

To assess the face validity of the constructs, the initial questionnaire was first pre-tested with several marketing academics and managers in the pharmaceutical industry as well as with ten professional buyers working in the bio-diagnostic industry. On the basis of their responses, a number of adjustments were made to the measurement scales to fit the specific characteristics of the sector.

In addition, the effects of four selected variables on the dependent constructs included in the proposed model were

Table A1

Construct items: item loadings, validity and reliability measures.

\begin{tabular}{|c|c|c|c|c|c|}
\hline Constructs/items & Loading & $t$-value & $\alpha$ & CR & AVE \\
\hline Customer orientation & & & .878 & .925 & .804 \\
\hline \multicolumn{6}{|l|}{${ }^{*} \mathrm{CO} 1-$ This salesperson tries to discover my needs } \\
\hline \multicolumn{6}{|l|}{${ }^{*} \mathrm{CO} 2$ - This salesperson has always my interest in mind } \\
\hline CO3-This salesperson tries to offer me the product/service that corresponds to my expectancies & .901 & 33.337 & & & \\
\hline CO4-This salesperson always offers me the product/service that is best suited to my needs & .881 & 25.909 & & & \\
\hline CO5-This salesperson tries to find out what kind of product/service would be most helpful to me & .908 & 33.232 & & & \\
\hline Team selling & & & .718 & .867 & .766 \\
\hline \multicolumn{6}{|l|}{ *Team2-We have team to plan and coordinate our activities } \\
\hline Team3-This salesperson has a team to plan and coordinate our activities & .946 & 9.119 & & & \\
\hline Distributive fairness & & & .873 & .912 & .722 \\
\hline DisFair1-The effort and investment your company has made to support the supplier's line & .829 & 9.312 & & & \\
\hline DisFair2-The roles and responsibilities the supplier assigns to your organization & .867 & 7.926 & & & \\
\hline \multicolumn{6}{|l|}{ *DisFair3-What the other dealers in our industry earn firm earns from sales through } \\
\hline DisFair4—What the supplier earns from selling to your company & .894 & 9.593 & & & \\
\hline DisFair5-The contributions your company makes to this supplier's marketing effort & .807 & 6.131 & & & \\
\hline Procedural fairness & & & .802 & .870 & .628 \\
\hline ProcFair1-The supplier and their personnel promote bilateral communication with customers & .861 & 24.313 & & & \\
\hline ProcFair2-We have many exchanges with this supplier & .667 & 7.559 & & & \\
\hline ProcFair3-A high level of two-way communication exists & .761 & 8.897 & & & \\
\hline ProcFair4-The supplier and their personnel apply consistent policies and procedures across all customers & .866 & 23.526 & & & \\
\hline \multicolumn{6}{|l|}{ *ProcFair5-The supplier sometimes alters his policies in response to dealer objections } \\
\hline \multicolumn{6}{|l|}{ *ProcFair6-The supplier seriously considers a dealer's objections to the supplier's policies } \\
\hline Satisfaction toward the salesperson & & & .867 & .918 & .790 \\
\hline SalSat1-The contacts I have with this salesperson are adequate & .873 & 26.690 & & & \\
\hline SalSat2-I am satisfied with the level of service this salesperson provides & .879 & 27.882 & & & \\
\hline SalSat3-In general, I am pretty satisfied with my dealings with this salesperson & .914 & 35.739 & & & \\
\hline Overall satisfaction (CANNON et PERRAULT, 1998) & & & .824 & .895 & .739 \\
\hline \multicolumn{6}{|l|}{ *OverSat1-Our firm does not regrets the decision to do business with this supplier } \\
\hline OverSat2-Overall, I am very satisfied with this supplier. & .861 & 25.354 & & & \\
\hline OverSat3- I am very pleased with what this supplier does for us. & .829 & 14.396 & & & \\
\hline OverSat4- Our firm is not completely happy with this supplier & .889 & 34.551 & & & \\
\hline \multicolumn{6}{|l|}{ *OverSat5-If we had to do it all over again, we would still choose to use this supplier } \\
\hline Anticipation of future interactions & & & .824 & .895 & .739 \\
\hline AFI1-It is probable that I will contact this salesperson again & .960 & 63.465 & & & \\
\hline AFI2-I am willing to discuss business with this salesperson again & .940 & 25.768 & & & \\
\hline AFI3-I plan to continue doing business with this salesperson & .958 & 61.395 & & & \\
\hline Loyalty toward the firm & & & .752 & .889 & .801 \\
\hline Loyalty $1-$ I will buy this product or service the next time I buy this product/service category & .906 & 39.730 & & & \\
\hline Loyalty2-I intend to continue to buy this product or service & .883 & 14.014 & & & \\
\hline \multicolumn{6}{|l|}{ *Loyalty3-I say positive things about this supplier to my co-workers } \\
\hline \multicolumn{6}{|l|}{ *Loyalty 4 - I would recommend this firm to someone seeking y advice } \\
\hline Competitive intensity & & & .909 & .931 & .731 \\
\hline Compet $1-$ Competition in our industry is cutthroat & .818 & 7.347 & & & \\
\hline Compet2-There are many "promotion wars" in our industry & .939 & 23.510 & & & \\
\hline Compet3-Anything than any competitor can offer, others can match readily & .823 & 7.753 & & & \\
\hline Compet 4 -Price competition is a hallmark in our industry & .902 & 14.019 & & & \\
\hline Compet5-One hears of a new competitive move almost every day & .782 & 7.342 & & & \\
\hline \multicolumn{6}{|l|}{ *Compet6-Ours competitors are relatively weak. } \\
\hline Market turbulence & & & .881 & .920 & .792 \\
\hline *Market1-In our kind of business, customers' product preferences change quite a bit over time & & & & & \\
\hline Market2-Our customers tend to look for new products all the time & .931 & 9.689 & & & \\
\hline *Market3-Sometimes our customers are very price-sensitive, but on other occasions, price is relatively unimportant & & & & & \\
\hline Market4-We are witnessing demand for our products and services from customers who never bought them before & .850 & 5.225 & & & \\
\hline Market5-New customers tend to have product-related needs that are different from those of our existing customers & .888 & 5.845 & & & \\
\hline
\end{tabular}


controlled for. Since prior research suggests that relationship history shapes subsequent interactions between exchange partners (Doney and Cannon, 1997), we controlled for the effect of the duration of the prior relationship. Moreover, since firm size, operationalized as the number of employees, has been shown to influence partners' attitude and behaviors (Boyle et al., 1992), its effects were also controlled for. Likewise, the effects of competitive intensity and market turbulence were also taken into account. Such environmental variables have proved to be significant predictors of the intentions of exchange partners in B-to-B relationships (Achrol et al., 1983; Dwyer et al., 1987; Geyskens et al., 1998; Jaworski and Kohli, 1993) and are thus related to their loyalty levels. Competitive intensity (the level of differentiation between competitors) and market turbulence (the rate of change in the composition of customers and their preference) were both measured using a sixitem scale developed by Jaworski and Kohli (1993).

\subsection{Data analysis}

The conceptual model presented in Fig. A1 was estimated using the partial least squares (PLS) procedure available in SmartPLS software (the program's default options were selected). PLS is a non-parametric estimation procedure (Wold, 1982; Chin, 1998) that was chosen because of (1) the restricted sample size compared to the number of manifest variables included in the model (Anderson and Gerbing, 1988; Chin and Newsted, 1999), (2) the limited number of indicators per construct (Hulland et al., 2010), and (3) the number of variables deviating from a normal distribution (Chin, 1998; Cassel et al., 1999; Chin et al., 2003). Resampling procedures were used to evaluate the statistical significance of parameters. Bootstrap technique was adopted with 200 replications to get "reasonable standard error estimates" (Tenenhaus et al., 2005).

In accordance with the two-step approach suggested by Anderson and Gerbing (1988), the testing and evaluation of PLS path models requires assessing the quality of the measurement model before analyzing the structural model and the proposed structural regression equations (Tenenhaus et al., 2005).

Before examining the structural model, we thus evaluated the reliability and validity of our measurements. As detailed in Table A1, all the item loadings are significant and greater than the 70 threshold. The average variance extracted (AVE) coefficient, which quantifies the amount of variance that a construct captures from its indicators relative to the amount due to measurement error (Chin, 1998), is well above the 50 threshold (Fornell and Larcker, 1981) for each construct, indicating adequate convergence. Taken as a whole, the preceding results confirm the convergent validity of the constructs used in this research.

Construct reliability was assessed using the Cronbach's alpha $(\alpha)$ and composite reliability (CR) indices. On the basis of these coefficients, a construct is considered reliable if $\alpha$ and CR are above the 70 threshold. As indicated in Table A1, all constructs are above these thresholds, thus validating construct reliability.

According to the Fornell-Larcker criterion (Fornell and Larcker, 1981), a construct is deemed discriminately valid if it shares more variance with its assigned indicators than with other latent variables. In statistical terms, this criterion compares the square root of AVE with the correlations among latent variables. Values presented in Table A2 demonstrate existence of discriminant validity, since the squared AVE values, the diagonal elements of the matrix, are greater that the pair-wise correlations, the nondiagonal elements.

Given that PLS path modeling lacks a global scalar function to optimize, it does not provide any kind of fit indices. The structural PLS model is thus mainly evaluated based on prediction-oriented measurements (Chin, 1998). Table A2 details the coefficients used to assess the quality of the proposed framework.

According to Chin (1998), $R^{2}$ values of 67, 33, and 19 in PLS path models are indicative of substantial, moderate, and weak performance, respectively. The average $R^{2}$ of the present model is 50 , which, based on Chin's thresholds, is a good value. However, it should be noted that the two endogenous variables related to the interorganizational level are better predicted by the model than the variables referring to the interpersonal level. In fact, overall satisfaction $\left(R^{2}=.568\right)$ and loyalty toward the firm $\left(R^{2}=.568\right)$ demonstrate a higher $R^{2}$ value than anticipation of future interactions $\left(R^{2}=.446\right)$ and satisfaction with the salesperson $\left(R^{2}=.469\right)$.

In PLS path modeling, the model's ability to predict may be evaluated using Stone-Geisser's $Q^{2}$. This blindfolding procedure provides cross-validated indices. While the cv-communality $\left(\mathrm{H}^{2}\right)$ coefficient measures the capacity of the model to predict the manifest variables directly from their own latent variables, the cvredundancy $\left(F^{2}\right)$ index estimates the capacity of the model to predict the endogenous manifest variables indirectly from their own latent variables using the related structural relations (Tenenhaus et al., 2005). In other words, $H^{2}$ assesses the quality of the measurement model for each construct while $F^{2}$ evaluates the quality of each structural equation. Overall, cross-validated values above zero provide evidence that the observed values are well reconstructed by the model and demonstrate its predictive relevance (Wold, 1982). Blindfolding results all meet this requirement (Table A2).

Although PLS path modeling lacks an index that can provide a global validation of the model fit, a global criterion of goodness-offit (GoF) can be computed as the geometric mean of the average communality and the average $R^{2}$ (Tenenhaus et al., 2005). In a recent paper, Wetzels et al. (2009) proposed that GoF values of 0.1, 0.25 , and 0.36 are respectively indicative of weak, moderate and substantial performance. With a GoF index of 62 , the proposed model performs well compared to the baseline values defined above (Tenenhaus et al., 2005; Wetzels et al., 2009).

Table A2

Constructs: descriptive, discriminant validity and model fit measures.

\begin{tabular}{|c|c|c|c|c|c|c|c|c|c|c|c|c|c|c|c|c|c|c|}
\hline Constructs & $M$ & SD & 1 & 2 & 3 & 4 & 5 & 6 & 7 & 8 & 9 & 10 & $R^{2}$ & Communality & $H^{2}$ & Redundancy & $F^{2}$ & GoF \\
\hline 1. Customer orientation & 3.80 & .86 & .90 & & & & & & & & & & - & .804 & .804 & - & - & - \\
\hline 2. Team selling & 2.96 & 1.18 & -.17 & .88 & & & & & & & & & - & .766 & .766 & - & - & - \\
\hline 3. Distributive fairness & 3.04 & .69 & .12 & .30 & .85 & & & & & & & & - & .722 & .722 & - & - & - \\
\hline 4. Procedural fairness & 3.34 & .77 & .31 & .25 & .46 & .79 & & & & & & & - & .628 & .628 & - & - & - \\
\hline 5. Satisfaction salesperson & 4.15 & .81 & .67 & -.25 & .04 & .25 & .89 & & & & & & .469 & .790 & .790 & .370 & .370 & - \\
\hline 6. Overall satisfaction & 3.95 & .81 & .57 & -.04 & .22 & .44 & .70 & .86 & & & & & .568 & .739 & .739 & .420 & .420 & - \\
\hline 7. Anticipation future interactions & 4.30 & .84 & .47 & -.09 & .18 & .42 & .61 & .65 & .95 & & & & .446 & .907 & .907 & .405 & .405 & - \\
\hline 8. Loyalty toward the firm & 4.00 & .79 & .37 & .02 & .21 & .46 & .52 & .62 & .66 & .86 & & & .518 & .801 & .801 & .415 & .415 & - \\
\hline 9. Competitive intensity & 3.30 & .96 & .25 & .05 & .46 & .44 & .12 & .20 & .15 & .24 & .85 & & - & .731 & .731 & - & - & - \\
\hline 10. Market turbulence & 2.97 & .96 & .15 & .15 & .47 & .39 & .02 & .21 & .18 & .17 & .62 & .89 & - & .792 & .792 & - & - & - \\
\hline Average & & & & & & & & & & & & & .500 & .768 & .768 & .403 & .403 & .620 \\
\hline
\end{tabular}

Note: Bold numbers on the diagonal show the square root of AVE for each construct. Numbers below the diagonal represent correlations between pair of constructs. 


\section{Results}

Table A3 summarizes the results of structural model. The significance of the path coefficients presented in the table allows confirming or not confirming the proposed hypotheses.

As regards the interpersonal level, two of the three proposed assumptions are confirmed. Indeed, according to $\mathrm{H} 1$, the salesperson's $\mathrm{CO}$ has a positive impact on the customer's satisfaction with the salesperson $(\beta=.647 ; p<.000)$. As the salesperson's CO increases, customers are more likely to be satisfied with their counterpart. In turn, consistently with $\mathrm{H} 3$, the results show that satisfaction with the salesperson has a positive influence on the customer's anticipation of future interactions with the salesperson $(\beta=.621 ; p<.000)$. As their level of satisfaction increases, customers are more likely to seek future contact with their counterpart. However, inconsistently with $\mathrm{H} 2$, no significant relationship was found between team selling and satisfaction with the salesperson $(\beta=-.141 ; p=.069)$.

With respect to the interorganizational level, the proposed hypotheses are validated. As postulated, distributive fairness $(\beta=.102 ; p<.044)$ and procedural fairness $(\beta=.241 ; p<.010)$ both have a positive, but weak, effect on the company's overall satisfaction, which, in turn, has a positive influence on the buying firm's loyalty toward the selling firm $(\beta=.318 ; p<.010)$. As the perceived level of distributive and procedural fairness increases, buying firms are more likely to be satisfied with, and ultimately loyal to, their supplier.

Hypotheses $\mathrm{H} 7$ and $\mathrm{H} 8$, postulating interaction effects between the interpersonal and the interorganizational level, were also confirmed. According to H7, the level of customer's satisfaction with the salesperson has a positive influence on the company's overall satisfaction with the selling firm $(\beta=.634 ; p<.000)$. As the level of a customer's satisfaction with the salesperson increases, buying firms are more likely to be satisfied with the overall relationship with their supplier. Likewise, according to $\mathrm{H} 8$, anticipation of future interactions with the salesperson has a positive impact on a firm's loyalty toward the selling firm $(\beta=.435$; $p<.009$ ). A buying firm is more likely to be loyal to the selling firm as the buyer anticipates having future interactions with the salesperson.

Table A3

Path coefficient results

\begin{tabular}{|c|c|c|c|}
\hline Hypotheses & $\begin{array}{l}\text { Path } \\
\text { coefficient }\end{array}$ & $\begin{array}{l}t- \\
\text { value }\end{array}$ & $\begin{array}{l}\text { Coefficient } \\
\text { significance }\end{array}$ \\
\hline $\begin{array}{l}\text { H1 C. Orientation } \rightarrow \text { Sat. with. } \\
\text { Salesp. }\end{array}$ & .647 & 11.224 & Sig. \\
\hline H2 T. Selling $\rightarrow$ Sat. with. Salesp & -.141 & 1.835 & Not Sig. \\
\hline $\begin{array}{l}\text { H3 Sat. with. Salesp } \rightarrow \text { Future } \\
\text { interactions }\end{array}$ & .621 & 6.413 & Sig. \\
\hline H4 Distri. Fairness $\rightarrow$ Overall sat. & .102 & 2.032 & Sig. \\
\hline H5 Proced. Fairness $\rightarrow$ Overall sat. & .241 & 3.124 & Sig. \\
\hline H6 Overall sat. $\rightarrow$ Loyalty & .318 & 2.602 & Sig. \\
\hline H7 Sat. with. Salesp $\rightarrow$ Overall sat. & .634 & 9.908 & Sig. \\
\hline $\begin{array}{l}\text { H8 Future interactions } \rightarrow \text { Loyalty } \\
\text { Control variables }\end{array}$ & .435 & 2.652 & Sig. \\
\hline $\begin{array}{l}\text { Market Turb. } \rightarrow \text { Future } \\
\text { interactions }\end{array}$ & .083 & 1.270 & Not Sig. \\
\hline Market Turb. $\rightarrow$ Loyalty & -.034 & .475 & Not Sig. \\
\hline $\begin{array}{l}\text { Relationship Age } \rightarrow \text { Future } \\
\text { interactions }\end{array}$ & .207 & 3.760 & Sig. \\
\hline Relationship Age $\rightarrow$ Loyalty & .016 & .271 & Not Sig. \\
\hline $\begin{array}{l}\text { Compet. Intens. } \rightarrow \text { Future } \\
\text { interactions }\end{array}$ & .071 & .721 & Not Sig. \\
\hline Compet. Intens. $\rightarrow$ Loyalty & .130 & 1.349 & Not Sig. \\
\hline Firm Size $\rightarrow$ Future interactions & .039 & 1.006 & Not Sig. \\
\hline Firm Size $\rightarrow$ Loyalty & .045 & .625 & Not Sig. \\
\hline
\end{tabular}

Regarding the effects of the proposed control variables (Market turbulence, Relationship duration, Competitive intensity and Firm size), only one of the paths included in the proposed framework was significant (see Table A3). In fact, results suggest that as the duration of the buyer-seller relationship increases, buyers are more likely to interact with the salesperson in the future $(\beta=.207 ; p<.000)$.

\section{Discussion, implications and limitations}

The results of this study show that considering the combined and interactive effects of employee contact performance and organizational fairness allows a better understanding of the dynamics of business relationships. Overall, the reported findings underscore the incremental value of a two-level approach and indicate that both interpersonal level and organizational level variables are needed to predict customer loyalty.

At the interpersonal level, the present research shows that the salesperson's CO has an important impact on the buyer-seller relationship. $\mathrm{CO}$ is a powerful determinant of a buyer satisfaction with the salesperson, which in turn, has a strong positive impact on overall satisfaction and loyalty toward the salesperson. Echoing Macintosh's (2007) findings, the present study demonstrates the importance of having customer-oriented employees at the individual and firm levels.

Contrary to the proposed hypothesis, the impact of team selling on satisfaction with the salesperson was not significant. This unexpected result suggests that team selling represents a minimal expectation in the biodiagnostic sector, which does not generate satisfaction and is not perceived by the buyer as a salient aspect of motivation. In other words, team selling is a necessary but not a sufficient condition for customer satisfaction. While all members of the team participate to find the best solution for the buying firm, the salesperson still needs to be customer oriented. The salesperson's CO is a key factor in B-to-B successful relationships.

At the interorganizational level, both distributive and procedural fairness have a positive effect on overall satisfaction with, and loyalty toward, the supplier. However, results demonstrate that the effects of distributive and procedural fairness on satisfaction are quite weak. Although surprising, these results are consistent with previous findings. For example, Kumar et al. (1995) conclude that distributive fairness has a moderate effect on satisfaction $(\beta=.208)$ while procedural fairness was not significantly related to satisfaction in Brown et al. (2006) study. One possible explanation may be proposed. Since interorganizational relationships entails both economic and social interactions, it may be argued that distributive and procedural fairness impact only one specific dimensions, with distributive fairness influencing economic interactions and procedural fairness affecting the social component. Another way to explain the weak effects of fairness on satisfaction may be related to the fact that only cognitive processes were considered in the proposed model. However, one can argue that affective processes are operative in B-to-B relationships and emotions may be considered as intervening variables between fairness and satisfaction. Finally, the potential interactions between distributive and procedural fairness could be another way to explain the present results. Nonetheless results demonstrate that procedural fairness has a stronger impact on satisfaction than distributive fairness suggesting that more than the output itself, it is the way the exchange process is handled that is most significant for the long-term evolution of the buyer-seller relationship. Furthermore, our results reveal the significant influence of satisfaction with the salesperson on customer loyalty. Indeed, satisfaction with the salesperson directly influences customer loyalty at the interpersonal level and has an indirect impact 
on customer loyalty at the interorganizational level. In other words, satisfaction with the salesperson is a good predictor of encounter performance, but is also a boundary variable between the interpersonal and interorganizational levels. Results even demonstrate that a firm's loyalty toward its supplier is more dependent on the buyer's anticipation of future interactions with the salesperson than on the firm's overall satisfaction, thus underlining the critical role played by salespersons in building customer loyalty. These findings have important implications for marketing theory and practice.

\subsection{Theoretical implications}

A number of theoretical implications can be derived from our findings. Our first contribution stems from considering both interpersonal level and organizational level antecedents of longterm relationships. As previously mentioned, existing research has focused independently on the role played by the salesperson and the perceived organizational fairness. Only a handful of studies have investigated the combined effects of the two levels. The present study thus offers additional insight into the determinants of customer loyalty. The theoretical development of our model and the study findings suggest a complex interplay of salesperson relationship and firm relationship.

At the interpersonal level, this research confirms that $\mathrm{CO}$ is a major antecedent of customer satisfaction. Indeed, in line with prior contributions (Saxe and Weitz, 1982; Goff et al., 1997), the present findings confirm the strong positive association linking CO to customer satisfaction.

Contrary to our prediction, team selling was not significantly associated with customer satisfaction with the salesperson. This result is particularly intriguing because it is inconsistent with prior research. Based on existing contributions (Workman et al., 2003; Guenzi et al., 2009), the proposed model assumed a positive effect of team selling on customer satisfaction. But no significant effect was found. This result may be explained by the nature of buyerseller interactions in this particular setting. Indeed, since the biodiagnostic sector involves highly complex products and services, coordination and team building may represent minimal expectations. Because of the complexity and technological sophistication involved, team selling may thus be considered as a requirement for operating in this sector. This possibility would explain why team selling has no influence on customer satisfaction.

Our findings also contribute to the relationship marketing literature by further documenting how salespersons may act as relationship enhancers. Indeed, consistent with previous findings (Crosby et al., 1990), the present results reveal that satisfied customers are more likely to seek future contact with the salesperson. Moreover, the findings show that salespersons are key drivers of customer loyalty. In line with prior research (Beatty et al., 1996; Goff et al., 1997; Reynolds and Beatty, 1999), the present study proves that satisfaction with the salesperson is a prime determinant of satisfaction with the organization, which, in turn, has a strong influence on firm loyalty.

With respect to organizational fairness, this research confirms that firm satisfaction and loyalty are dependent upon fairness perceptions. Indeed, distributive and procedural fairness are positively related to satisfaction with the firm. Such findings are consistent with much of the existing literature, suggesting that fairness develops through tangible aspects of the firm's service and policies. However, the results show that procedural fairness is more important than distributive fairness in developing satisfaction. Consequently, while economic rewards that flow from the relationship are crucial, the way benefits and burdens are distributed is a more powerful driver of customer satisfaction.

\subsection{Managerial implications}

As previously mentioned, customers are more likely to be satisfied and subsequently loyal when they interact with customer-oriented salespersons. Customer orientation entails a relational attitude directed toward understanding the customer's needs. Because $\mathrm{CO}$ is a powerful driver of customer loyalty, suppliers are advised to invest substantially in actions intended to increase CO. The reported effect of salesperson relational behaviors on the buyer-seller interaction process and outcome (overall company satisfaction and loyalty) raises one fundamental question: How can the salesforce be turned toward customer orientation? One possible answer is related to salesperson recruiting procedures. Indeed, Brown et al. (2002) suggested that CO is a personality trait that can be identified using personality tests. Suppliers are thus advised to select salespeople who score high on the agreeability component and who score low on the neuroticism dimension of the Big Five Personality Test. Likewise, Pettijohn et al. (2010) found that salesperson emotional intelligence levels are positively correlated with their customer-orientation. Emotional intelligence encompasses a set of individual (self-awareness, selfregulation) and social (social skills, empathy) competencies driving individuals to engage in performance-promoting activities and behaviors. Consequently, emotional intelligence levels could be used during the salesforce recruiting and training processes as a way to improve customer-orientation levels. Moreover, following Humphreys and Williams's (1996) suggestions, we argue that CO may be cultivated through dedicated training programs and specific motivating and rewarding procedures. Moreover, we believe that managers have a crucial role in developing a customer oriented culture (Schwepker and Good, 2004).

The second set of implications is related to the means a firm can use to set up "fair" treatment. Results related to fairness suggest practical implications regarding the conditions required to be perceived as a fair exchange partner. Indeed, the reported findings demonstrate that both distributive and procedural fairness have important implications for the way customers assess their relationship. To be perceived as a fair partner thus requires suppliers to develop margins and outcomes, as well as fair procedures and policies. As the literature suggests, more than the output, it is the way that the product/service is acquired that is most important for establishing a long-term relationship. More importantly, our results also show that procedural fairness is a more powerful driver of customer satisfaction than distributive fairness. In other words, the procedure and processes that suppliers implement in relation to their customers are more important in building customer satisfaction and loyalty than the mere earnings and outcomes that customers receive from the relationship with their supplier. Consequently, firms are advised to develop frequent contact and demonstrate that they offer personalized treatment to the buyer.

\subsection{Limitations and future research}

Although this research sheds light on important issues, several limitations must be noted. First, the data used to assess the proposed framework was collected from buyers operating in a specific industry. This setting inevitably restricts the generalizability of this study. Thus cross-validation in other contexts is required. For example, the banking or insurance sectors could be considered, as they involve less complexity and technological sophistication. Moreover, since the specific function of the respondents may influence the way they evaluate and interact with their supplier, further research should investigate how this variable affects the proposed model. Second, the study sample was essentially composed of SMEs. Because SMEs have idiosyncratic 
characteristics compared to larger organizations, the reported buying behaviors and attitudes may not apply to the whole population of B-to-B buyers. In fact, the development of customer loyalty in larger firms may be very different. Consequently, analyzing in more details the potential effect of firm size on the interpersonal and interorganizational dimensions of loyalty would add to our understanding of interfirm interaction processes. Third, the present results suggest the need for further investigation into the customer-employee relationship. Our study only took into account two dimensions of salespeople's relational behavior ( $\mathrm{CO}$ and team selling). But existing contributions suggest that salespeople's relational behaviors include other dimensions such as listening and conflict resolution. Future research should broaden the proposed framework by investigating the impact of these variables on customer satisfaction and loyalty. In fact, a qualitative research with B-to-B customer would bring additional insights into the determinants of customer orientation. Moreover, in-depth interviews may also help understand why team selling is not regarded as a determinant of satisfaction in the investigated sector.

Likewise, while this study adds to our understanding of the effects of fairness in the B-to-B relationship, the determinants of perceived fairness were not considered. Our results show that perceived fairness has a positive and significant influence on satisfaction and loyalty toward the firm, but further research should include other determinants and consequences of fairness such as recovery policies, trust or commitment. Overall, we focused on the consequences of $\mathrm{CO}$ and perceived fairness. Additional investigations aimed at exploring the antecedents of these concepts - such as the firm's selling orientation, sales force control systems, or pay and incentives policies - may add to our understanding.

We also believe that further development of our model is needed. There are still many unresolved issues related to the topic addressed in this paper. For example, the literature on emotions in business relationships increasingly recognizes that affect, not just cognition, influences decision-making processes. Even in the B-to$B$ marketing literature, a growing number of studies highlight the role played by emotions (Andersen and Kumar, 2006; Wang and Huff, 2007; Tähtinen and Blois, 2011). However, to date, only a handful of scholars have expressly investigated the effects of affective states in B-to-B relationship dynamics. The few existing studies offer very stimulating avenues for research. Indeed, their contributions reveal how emotions that emerge at the individual level may shape the level of cooperation at the interorganizational level (Andersen and Kumar, 2006; Tähtinen and Blois, 2011). Consequently, future studies on the topic should aim to extend the proposed framework by examining the potential influence of emotions.

Furthermore, investigating why and when customers may decide either to enhance or to end a business relationship could complement the present findings. More specifically, while the marketing literature has paid considerable attention to the development of business relationships, a growing body of evidence shows that dissolutions are quite common in B-to-B partnerships (Geyskens and Steenkamp, 2000; Ping, 1993). Although a growing interest has emerged in the literature regarding the so-called dark side of business relationships (e.g. Alajoutsijärvi et al., 2000; Halinen and Tähtinen, 2002; Tähtinen, 2002), problematic episodes deserve further examination. Within this perspective, the effects of salesperson behavior and organizational fairness may be considered as significant drivers of customer defection.

\section{References}

Achrol, R.S., Reve, T., Stern, L.W., 1983. The environment of marketing channel dyads: a framework for comparative analysis. Journal of Marketing 47 (4), 55-67.
Adams, J.S., 1963. Toward an understanding of inequity. Journal of Abnormal and Social Psychology 67 (5), 422-436.

Adams, J.S., 1965. Inequity in social exchange. In: Berkowitz, L. (Ed.), Advances in Experimental Social Psychology, vol. 2. Academic Press, New York, pp. 267-299. Alajoutsijärvi, K., Möller, K., Tähtinen, J., 2000. Beautiful exit: how to leave your business partner. European Journal of Marketing 34 (11/12), 1270-1289.

Andersen, P.H., Kumar, R., 2006. Emotions, trust and relationship development in business relationships: a conceptual model for buyer-seller dyads. Industrial Marketing Management 35 (4), 522-535.

Anderson, J.C., Gerbing, D.W., 1988. Structural equation modeling in practice: a review and recommended two-step approach. Psychological Bulletin 103 (3), 411-423.

Bagozzi, R.P., 1975. Marketing as exchange. Journal of Marketing 39 (4), 32-39.

Beatty, S.E., Mayer, M., Coleman, J.E., Reynolds, K.E., Lee, J., 1996. Customer-sales associate retail relationships. Journal of Retailing 72 (3), 223-247.

Berry, L.L., 1995. Relationship marketing of services-growing interest, emerging perspectives. Journal of the Academy of Marketing Science 23 (4), 236-245.

Berry, L.L., Parasuraman, A., Zeithaml, V.A., 1994. Improving service quality in America: lessons learned. Academy of Management Executive 8 (2), 32-52.

Biong, H., Selnes, F., 1996. The strategic role of the salesperson in established buyerseller relationships. Journal of Business-to-Business Marketing 3 (3), 39-78.

Bitner, M.J., 1990. Evaluating service encounters: the effects of physical surroundings and employee responses. Journal of Marketing 54 (2), 69-82.

Bitner, M.J., Hubbert, A.R., 1994. Encounter satisfaction versus overall satisfaction versus quality: the customer's voice. In: Rust, R.T., Oliver, R.L. (Eds.), Service Quality: New Directions in Theory and Practice. Sage, London, pp. 79-94.

Bolton, R.N., Lemon, K.N., 1999. A dynamic model of customers' usage of services: usage as an antecedent and consequence of satisfaction. Journal of Marketing Research 36 (2), 171-186.

Boyle, B., Dwyer, R.F., Robicheaux, R.A., Simpson, J.T., 1992. Influence strategies in marketing channels: measures and use in different relationship structures. Journal of Marketing Research 24 (4), 462-473.

Brown, J.R., Cobb, A.T., Lusch, R.F., 2006. The role played by interorganizational contracts and justice in marketing channel relationship. Journal of Business Research 59 (2), 166-175.

Brown, T.J., Mowen, J.C., Donovan, T.D., Licata, J.W., 2002. The customer orientation of service workers: personality trait effects on self and supervisor performance. Journal of Marketing Research 19 (1), 110-119.

Cannon, J.P., Perreault, W.D., 1999. Buyer-seller relationships in business markets. Journal of Marketing Research 36 (4), 439-460.

Cassel, C., Hackl, P., Westlund, A.H., 1999. Robustness of partial least-squares method for estimating latent variable quality structures. Journal of Applied Statistics 26 (4), 435-446.

Chin, W.W., 1998. The partial least square approach for structural equation modelling. In: Marcoulides, G.A. (Ed.), Modern Methods for Business Research. Lawrence Erlbaum Associates, London, pp. 295-336.

Chin, W.W., Newsted, P.R., 1999. Structural equation modeling analysis with small samples using partial least squares. In: Hoyle, R.H. (Ed.), Statistical Strategies for Small Sample Research. Sage, California, pp. 307-342.

Chin, W.W., Marcolin, B.L., Newsted, P.R., 2003. A partial least squares latent variable modeling approach for measuring interaction effects: results from a Monte Carlo simulation study and an electronic-mail emotion/adoption study. Information Systems Research 14 (2), 189-217.

Clemmer, E.C., 1993. An investigation into the relationships of justice and customer satisfaction with services. In: Cropanzano, R. (Ed.), Justice in the Workplace: Approaching Fairness in Human Resource Management. Erlbaum, Hillsdale, NJ, pp. 193-207.

Crosby, L.A., Evans, K.R., Cowles, D., 1990. Relationship quality in services selling an interpersonal influence perspective. Journal of Marketing 54 (3), 68-81.

Dick, A.S., Basu, K., 1994. Customer loyalty: toward an integrated conceptual framework. Journal of the Academy of Marketing Science 22 (2), 99-113.

Doney, P.M., Cannon, J.P., 1997. An examination of the nature of trust in buyerseller relationships. Journal of Marketing 61 (2), 35-51.

Dorsch, M.J., Swanson, S.M., Kelley, S.W., 1998. The role of relationship quality in the stratification of vendors as perceived by customers. Journal of the Academy of Marketing Science 26 (2), 128-142.

Dwyer, F.R., Schurr, P.H., Oh, S., 1987. Developing buyer-seller relationship. Journal of Marketing 51 (2), 11-27.

Eiglier, P., Langeard, E., 1987. Servuction-Le marketing des Services. Ediscience International.

Fornell, C., 1992. A national customer satisfaction barometer: the Swedish experience. Journal of Marketing 56 (1), 6-21.

Fornell, C., Wernefelt, B., 1987. Defensive marketing strategy by customer complaint management: a theoretical analysis. Journal of Marketing Research 24 (4), 337-346.

Fornell, C., Johnson, M.D., Anderson, E.W., Cha, J., Everitt, B.B., 1996. The American customer satisfaction index: nature, purpose and findings. Journal of Marketing 60 (4), 7-18.

Fornell, C., Larcker, D.F., 1981. Evaluating structural equations models with unobservable variables, measurement error. Journal of Marketing Research 18 (1), 39-50.

Frazier, G.L., Spekman, R.E., O'Neal, C.R., 1988. Just-in-time exchange relationships in industrial markets. Journal of Marketing 52 (4), 52-67.

Ganesan, S., 1994. Determinants of long-term orientation in buyer-seller relationships. Journal of Marketing 58 (2), 1-19. 
Geyskens, I., Steenkamp, J.B., 2000. Economic and social satisfaction: measurement and relevance to marketing channel relationships. Journal of Retailing 76 (1), $11-32$.

Geyskens, I., Steenkamp, J.B., Kumar, N., 1998. Generalizations about trust in marketing channel relationships using meta-analysis. International Journal of Research in Marketing 15 (3), 223-248.

Geyskens, I., Steenkamp, J.B., Kumar, N., 1999. A meta-analysis of satisfaction in marketing channel relationships. Journal of Marketing Research 36 (2), 223-238.

Goff, G., Boles, J.S., Bellenger, D.N., Stojack, C., 1997. The influence of salesperson selling behaviors on customer satisfaction with the products. Journal of Retailing 63 (2), 70-87.

Goodwin, C., Ross, I., 1992. Customer responses to services failures: influence of procedural and interactional fairness perceptions. Journal of Business Research 25 (2), 149-163.

Grewal, D., Sharma, A., 1991. The effect of salesforce behaviour on customer satisfaction: an interactive framework. Journal of Personal Selling and Sales Management 11 (3), 13-23.

Guenzi, P., Georges, L., Pardo, C., 2009. The impact of strategic account managers' behaviors on relational outcomes: an empirical study. Industrial Marketing Management 38 (3), 300-311.

Gundlach, G.T., Murphy, P.E., 1993. Ethical and legal foundations of relational marketing exchanges. Journal of Marketing 57 (4), 35-46.

Halinen, A., Tähtinen, J., 2002. A process theory of relationship ending. International Journal of Service Industry Management 13 (2), 163-180.

Hulland, J., Ryan, M.J., Rayner, R.K., 2010. Modeling customer satisfaction: a comparative performance evaluation of covariance structure analysis versus partial least squares. In: Esposito Vinzi, V., Chin, W.W., Henseler, J., Wang, H. (Eds.), Handbook of Partial Least Squares. Springer, Berlin, pp. 307-325.

Humphreys, M.A., Williams, M.R., 1996. Exploring the relative effects of salesperson interpersonal process attributes and technical product attributes on customer satisfaction. Journal of Personal Selling and Sales Management 16 (3), 47-57.

Jap, S.D., 1999. Pie-expansion efforts: collaboration processes in buyer-supplier relationships. Journal of Marketing Research 36 (4), 461-475.

Jap, S.D., 2001. Pie sharing in complex collaboration contexts. Journal of Marketing Research 38 (1), 86-99.

Jaworski, B.J., Kohli, A.K., 1993. Market orientation: antecedents and consequences. Journal of Marketing 57 (3), 53-70.

Kumar, N., Scheer, L.K., Steenkamp, J.B., 1995. The effects of supplier fairness on vulnerable resellers. Journal of Marketing Research 32 (3), 348-356.

Liu, A.H., Leach, M.P., 2001. Developing loyal customers with a value-adding sales force: examining customer satisfaction and the perceived credibility of consultative salespeople. Journal of Personal Selling and Sales Management 21 (2), 147-157.

Macintosh, G., 2007. Customer orientation, relationship quality, and relational benefits to the firm. The Journal of Services Marketing, 150-159.

Macintosh, G., Lockshin, L.S., 1997. Retail relationships and store loyalty: a multilevel perspective. International Journal of Research in Marketing 14 (5), 487-497.

Maxham III, J.G., Netemeyer, R.G., 2003. Firms reap what they sow: the effects of shared values and perceived organizational justice on customers' evaluations of complaint handling. Journal of Marketing 67 (1), 46-62.

Mittal, V., Kamakura, W.A., 2001. Satisfaction, repurchase intent, and repurchase behavior: investigating the moderating effect of customer characteristics. Journal of Marketing Research 38 (2), 131-142.

Oliver, R.L., 1981. Measurement and evaluation of satisfaction processes in retail settings. Journal of Retailing 57 (3), 49-68.

Oliver, R.L., 1997. Satisfaction. A Behavioral Perspective on the Consumer. McGrawHill, New York, NY.

Oliver, R.L., 1999. Whence consumer loyalty? Journal of Marketing, Special Issue 63 (4), 33-44.

Oliver, R.L., Swan, J.E., 1989. Consumer perceptions of interpersonal equity and satisfaction in transactions: a field survey approach. Journal of Marketing 53 (2), 21-35.

Palmatier, R.W., Dant, R.P., Grewal, D., Evans, K., 2006. Factors influencing the effectiveness of relationship marketing: a meta-analysis. Journal of Marketing 70 (4), 136-153.

Parasuraman, A., Zeithaml, V.A., Berry, L.L., 1991. Understanding customer expectations of service. Sloan Management Review Spring, 39-48.
Perry, M.L., Pearce, C.L., Sims, H.P., 1999. Empowered selling teams: how shared leadership can contribute to selling team outcomes. Journal of Personal Selling \& Sales Management 19 (3), 35-51.

Pettijohn, C.E., Rozell, E.J., Newman, A., 2010. The relationship between emotional intelligence and customer orientation for pharmaceutical salespeople: a UK perspective. International Journal of Pharmaceutical and Healthcare Marketing 4 (1), 21-39.

Ping, R.A., 1993. The effects of satisfaction and structural constraints on retailer exiting, voice, loyalty, opportunism, and neglect. Journal of Retailing 69 (3), 320-352.

Ramsey, R.P., Sohi, R.S., 1997. Listening your customers: the impact of perceived salesperson listening behavior on relationship outcomes. Journal of the Academy and Marketing Science 25 (2), 127-135.

Reichheld, F.F., Sasser, W.E., 1990. Zero defections: quality comes to services. Harvard Business Review 68, 105-111 September-October.

Reynolds, K.E., Beatty, S.E., 1999. Customer benefits and company consequences of customer-salesperson relationships in retailing. Journal of Retailing 75 (1), 11-32.

Ring, P.S., Van de Ven, A.H., 1994. Developmental processes of cooperative interorganizational relationships. Academy of Management Review 19 (1), 90-118.

Saxby, C.L., Tat, P.K., Johansen, J.T., 2000. Measuring consumer perceptions of procedural justice in a complaint context. Journal of Consumer Affairs 34 (2), 204-216.

Saxe, R., Weitz, B., 1982. The S.O.C.O scale: a measure of customer orientation of salespeople. Journal of Marketing Research 19 (3), 343-351.

Schultz, R.J., Evans, K.R., 2002. Strategic collaborative communication by key account representatives. Journal of Personal Selling \& Sales Management 22 (1), 23-31.

Schwepker, C.H., Good, D.J., 2004. Marketing control and sales force customer orientation. Journal of Personal Selling and Sales Management 24 (3), 167-179.

Sparks, B.A., McColl-Kennedy, J.R., 1998. The application of procedural justice principles to service recovery attempts: outcomes for customer satisfaction. Advances in Consumer Research 25 (1), 156-161.

Tähtinen, J., 2002. The process of business relationship ending-its stages and actors. Journal of Market-Focused Management 5 (4), 331-353.

Tähtinen, J., Blois, K.J., 2011. The involvement and influence of emotions in problematic business relationships. Industrial Marketing Management 40 (6) 907-918.

Tax, S.S., Brown, S.W., Chandrashekaran, M., 1998. Customer evaluations of service complaint experiences: implications for relationship marketing. Journal of Marketing 62 (2), 60-76.

Tenenhaus, M., Esposito Vinzi, V., Chatelin, Y.M., Lauro, C., 2005. PLS path modeling. Computational Statistics \& Data Analysis 48 (1), 159-205.

Thibaut, J., Walker, L., 1978. A theory of procedure. California Law Review 66 (3) 541-566.

Thomas, R.W., Soutar, G.N., Ryan, M.M., 2001. The selling orientation-customer orientation scale: a proposed short form. Journal of Personal Selling \& Sales Management 21 (1), 63.

Vázquez-Casielles, R., Suárez Álvarez, L., Díaz Martín, A.M., 2010. Developing loyal customers with a value-adding sales force: examining customer satisfaction and the perceived credibility of consultative salespeople. Psychology \& Marketing 27 (5), 487-509.

Wang, S., Huff, L.C., 2007. Explaining buyers' responses to sellers' violation of trust European Journal of Marketing 41 (9/10), 1033-1052.

Wetzels, M., Odekerken-Schröder, G., Van Oppen, C., 2009. Using PLS path modeling for assessing hierarchical construct models: guidelines and empirica illustration. MIS Quarterly 33 (1), 177-195.

Williams, M., Attaway, M.R., 1996. Exploring salespersons' customer orientation as a mediator of organizational culture's influence on buyer-seller relationship. Journal of Personal Selling and Sales Management 16 (4), 33-52.

Wold, H., 1982. Soft modeling: the basic design and some extensions. In: Jöreskog, K.G., Wold, H. (Eds.), Systems Under Indirect Observation-Part 2. Elsevier, Amsterdam, pp. 1-54.

Workman, J.P., Homburg, C., Jensen, O., 2003. Intraorganizational determinants of key account management effectiveness. Journal of the Academy of Marketing Science 31 (1), 3-21. 